\title{
THE CONTRIBUTION OF PERCEIVED FIRM MARKETING INNOVATION INITIATIVES TO CUSTOMER PERCEIVED VALUE AND LOYALTY: DOES SWITCHING EXPERIENCE REALLY MATTER?
}

\author{
Stephanie Hui-Wen Chuah ${ }^{1 *}$, Malliga Marimuthu ${ }^{2}$ and T. Ramayah ${ }^{1,3}$ \\ ${ }^{1}$ School of Management, Universiti Sains Malaysia, 11800 Pulau Pinang, Malaysia \\ ${ }^{2}$ School of Business, Charles Darwin University, 21 Kitchener Drive, \\ Darwin NT 0800, Australia \\ ${ }^{3}$ UTM International Business School (UTM-IBS), Universiti Teknologi Malaysia, \\ 54100 Kuala Lumpur, Malaysia \\ *Corresponding author: hw.chuah@gmail.com
}

Published online: 30 December 2016

To cite this article: Chuah, S.H.W., Marimuthu, M., and Ramayah, T. (2016). The contribution of perceived firm marketing innovation initiatives to customer perceived value and loyalty: Does switching experience really matter? Asian Academy of Management Journal, 21(Supp. 1), 1-23. http://dx.doi.org/10.21315/aamj2016.21.supp.1.1

To link to this article: http://dx.doi.org/10.21315/aamj2016.21.supp.1.1

\begin{abstract}
In recent years, perceived firm marketing innovation initiatives (PFMII) are increasingly considered as an important means to ensure customers' continued loyalty. Although customer perceived value is believed to be a potential mediator between PFMII and customer loyalty, much of the evidence to date remains anecdotal or speculative. Furthermore, there is a dearth of knowledge about how the effect of PFMII on customer value differs between switchers and non-switchers. To bridge this knowledge gap, we propose a conceptual framework linking PFMII to customer perceived value and loyalty, and develop hypotheses about the moderating role of switching experience in some of these linkages. Data were collected from Generation Y(18-34 years old) who subscribed to post-paid mobile internet plans. The results showed that both functional and monetary values mediated the relationship between PFMII and customer loyalty. However, there was no significant difference in the effect of PFMII on functional and monetary values between switchers and non-switchers. This research contributes to theory and practice by clarifying linkages between PFMII and customer loyalty by investigating the often widely neglected role of customer perceived value. In addition, this study successfully extended Sweeney
\end{abstract}


and Soutar (2001) PERVAL model by incorporating PFMII as the key driver of customer perceived value.

Keywords: perceived firm marketing innovation initiatives, customer perceived value, customer loyalty, switching experience, generation $\mathrm{Y}$, mobile internet service

\section{INTRODUCTION}

"A business which is serious about competing in fast-changing markets with fast changing technology must make this happen - it must innovate. If it does not innovate it risks being overtaken by competitors" (Johne, 1999, p. 6)

An increasingly competitive and volatile marketplace of the twenty-first century, together with profound changes in customer lifestyles, compelled firms to embark on marketing innovation initiatives to meet customers' evolving needs (Stock, 2011). From a firm's perspective, marketing innovation initiatives can be an important source of competitive advantage en route to superior performance (Naidoo, 2010): it provides the means to distinguish a firm's products from its competitors, aiding a firm to achieve sustainable and unequivocal market leadership (Gehlhar, Regmi, Stefanou, \& Zoumas, 2009; Kandampully \& Duddy, 1999). From a customer's perspective, marketing innovation initiatives can primarily demonstrate a firm's ongoing commitment to innovation, thereby elevating a firm's image in the mind of its customers. An innovative firm image has a significantly positive impact upon firm credibility, making a firm to be more professional, more attractive, and more trustworthy in the eyes of customers (Chen, 2001). In this sense, innovation constitutes a competitive weapon in convincing customers to choose one company over another.

Advances in mobile technology, marked by successive generations, such as $2.5 \mathrm{G}, 3 \mathrm{G}$, and $4 \mathrm{G}$, led to quantum leaps in data transfer speed that manifest in fast internet access and enhanced data streaming (Lam \& Shankar, 2014). These improvements, together with the rapid adoption of smartphones and the growing popularity of mobile operating systems (e.g. Apple's iOS and Google's Android), fuelled towards tremendous growth in mobile internet subscriptions. Moreover, given the fact that mobile internet is a combination of the two hottest technological innovations in recent times (mobile phones and the internet), many analysts and market research firms painted a rosy future for mobile internet (Jiang, 2009), especially in emerging markets like Asia (Wagstaff \& Lee, 2013). For instance, eMarketer estimates the number of mobile internet users in the Asia Pacific region 
will grow exponentially from 473.2 million in 2010 to approximately 1.22 billion by 2015 (Statista, 2015). As the number of mobile internet users continues to grow at an astonishing pace, mobile internet is poised to become one of the most promising and lucrative growth markets globally (Roostika, 2011). According to Pricewaterhouse Coopers's $(\mathrm{PwC})$ latest forecast, global mobile internet service revenue will be worth US\$259 billion in 2014 and exceed US\$385 billion by 2017 , accounting for $58 \%$ of overall internet access expenditure. Notably, the prediction is that global spending on mobile internet access will exceed that of fixed broadband lines in 2014, driven substantially by emerging markets, such as Asia (Huang, 2013).

Malaysia, like other Asian countries,witnessed an extraordinary growth in the numbers of mobile internetusers. According to the annual Yahoo! Net Index Survey 2011, the mobile internet segment in Malaysia has more than doubled since 2010 with growth fuelled mainly by Generation Y consumers in the 15-to-25 year age group (New Straits Times, 2011). Surging demand for mobile internet service was accompanied by an increase in mobile operators (both traditional and virtual), which aim to grab bigger proceeds from this opportunity. The consequence of this phenomenon was an appearance of ferocious competition among mobile operators. The fierce competition requires mobile operators to be extremely innovative in their marketing strategies in order to gain a higher market share (Roostika, 2012). In Malaysia, mobile operators regularly launch new products or services, in response to customers who continuously develop new needs and wants. For example, U Mobile Sdn. Bhd. introduced the first all-in-one post-paid plan in Malaysia, in which customers are allowed to share call minutes and with an internet quota with up to 3 SIM (subscriber identity module) cards. The plan also offers customers free internet roaming across Asia, free calls to U Mobile friends all day and night, and also unlimited internet with no extra charges after exceeding quota. Significant innovation allows a firm to establish a competitively dominant position by differentiating its customer value proposition from that of its competitors (Danneels \& Kleinschmidtb, 2001; Kim, Kim, Garrett, \& Jung, 2015). Embarking on marketing innovation initiatives further signals to customers that a firm intensively tries to fulfil their evolving needs by making continuous investments into innovation, leading to enhanced satisfaction and loyalty (Stock, 2011). In addition, Kandampully and Duddy (1999) contended that customers will be inclined to maintain a long-term relationship only if the firm maintains their market leadership, both in exceptional service and innovation.

Despite the well-recognised significance of marketing innovation initiatives on customer-firm relationships, paradoxically, little interest was shown in understanding the mechanisms by which perceived firm marketing innovation 
initiatives (PFMII) contribute to the loyalty formation in the context of mobile internet service. Sawhney, Wolcott, and Arroniz (2011) believed that innovation is relevant only if it creates value for customers. However, there have hitherto been no studies that investigated whether customer perceived value acts as a mechanism that converts PFMII into customer loyalty. Furthermore, not much is known about how the effect of PFMII on value perception differs between customers who switched mobile operators (switchers) and those who have not (non-switchers). Differences are likely to exist because customers with high switching rates experienced in the past will be more demanding and difficult to satisfy than those with no experience, as they have greater knowledge of how a product or service should be performed (Sharma \& Patterson, 2000; Matzler, Strobl, Thurner, \& Füller, 2015). Knowing how these effects differ on switching experience can help mobile operators develop more effective marketing innovation and customer retention strategies for different customer groups (e.g. switchers versus non-switchers).

To address the aforementioned literature gap, this study examines the role of PFMII in the process of customer value and loyalty formation. More specifically, the study (1) investigates the effect of PFMII on functional and monetary values, (2) tests the effects of functional and monetary values on emotional value, (3) examines the effect of each perceived value dimension (e.g. functional, emotional, and monetary values) on customer loyalty, (4) investigates the mediating effects of functional and monetary values on the relationship between PFMII and customer loyalty, and (5) examines the moderating effect of switching experience (switchers versus nonswitchers) on the relationship between PFMII and two perceived value dimensions (functional and monetary values).

The remainder of this paper is organised as follows. First, it reviews the relevant literature, develops study hypotheses and proposes the conceptual framework. Next, it describes the methodology employed for this study and presents the results of the statistical data analysis. Finally, the paper discusses theoretical and practical implications of this study as well as its limitations.

\section{LITERATURE REVIEW}

\section{Perceived Firm Marketing Innovation Initiatives}

According to the Organisation for Economic Co-operation and Development's (OECD) Oslo Manual (2005, p. 49), marketing innovation is, "the implementation of a new marketing method involving significant changes in product design or 
packaging, product placement, product promotion or pricing." (OECD, 2005, p. 49). Wang and Ahmed (2004), contrastingly, describe marketing innovation as "the newness of approaches that firms adopt to enter and exploit the targeted market" (p. 305). Based on the synthesis of previous definitions, a firm's marketing innovation initiatives is defined here as, "customers' perception about the capability of a focal mobile operator to engage in marketing innovation initiatives; that is, the introduction of new products or services, the use of new pricing strategies, and the adoption of new methods for promoting and selling the firm's products" (Hult, Hurley, \& Knight, 2004; OECD, 2005).

From a consumer perspective, Andrews and Smith (1996) averred that there were two basic dimensions to marketing programs' innovativeness: (1) "perceived novelty" - the magnitude of the difference between a firm's most recent marketing programs and the competitors' programs, and (2) "perceived meaningfulness" - the degree to which the marketing initiatives are deemed as attractive or valuable to the target customers. In brief, the innovativeness of a firm's marketing initiatives depends on the extent to which customers perceive the marketing mix elements (e.g. product, price, promotion, and distribution) embedded in a firm's marketing strategies to be a meaningful novelty (Bloch, 2007; Rust, Ambler, Carpenter, Kumar, \& Srivastava, 2004). Product (or service) innovation involves the introduction of products or services that are new or significantly improved with respect to their technical specifications or functional characteristics. Pricing innovation involves the use of new pricing tactics to market the firm's products or services. Promotion innovation involves the use of new concepts and inventive approaches (e.g. new advertising methods and new brand symbols) to promote a firm's products or services. Distribution and/or sales channels innovation involves the introduction of new distribution or sales channels to sell products and services to customers in an efficient manner (Bloch, 2007; OECD, 2005).

\section{Customer Perceived Value}

The concept of customer perceived value became a major focus in contemporary marketing due to the paradigm shift from transactional marketing towards relationship marketing (Sinha \& DeSarbo, 1998; Ulaga \& Chacour, 2001), which refers to "all marketing activities directed toward establishing, developing, and maintaining successful relational exchanges" (Morgan \& Hunt, 1994, p. 22). From the customer's point of view, attaining value is a fundamental purchase goal and is crucial to all successful exchange transactions (Holbrook, 1994). Therefore, understanding what customers value and seeking to deliver that is one cornerstone of effective marketing programmes (Caruana \& Fenech, 2005). Indeed, creating 
and delivering superior customer value is a necessary condition for a company securing a niche in a competitive environment, not to mention a leadership position in the market (Lai, 1995, p. 381).

Customer perceived value was given many definitions in the literature, and one of the most commonly cited definitions is as put forth by Zeithaml (1988, p. 14), who defined value as, "the consumer's overall assessment of the utility of a product based on perceptions of what is received and what is given"(e.g. Chen \& Hu, 2010; Lee, Yoon, \& Lee, 2007; Lin, Sher, \& Shih, 2005; Sánchez-Fernández \& Iniesta-Bonillo, 2007). Zeithaml's (1988) definition reflects four diverse meanings of value: (1) value is low price, (2) value is whatever the consumer wants in a product, (3) value is the quality that the consumer obtained for the price paid, and (4) value is what the consumer gets for what he/she gives. To put it simply, perceived value involves a trade-off between what the customer gets (e.g. quality, benefits, utilities) and what they give up (e.g. prices, sacrifices, time) to purchase and consume a product (Mayr \& Zins, 2012). Although creating superior customer value is increasingly seen as a key element for ensuring firms' success and survival (Khalifa, 2004), there is little consensus in regards to the conceptualisation of this construct (Boksberger \& Melsen, 2011). Some researchers adopted a unidimensional approach and globally measured overall customer value perceptions (e.g. Chen \& Chang, 2012; Chen, 2013; Wu, Chen, Chen, \& Cheng, 2014) whereas other researchers employed a multidimensional approach and measured perceived value using various get (benefit) and give (sacrifice) components (e.g. Sweeney \& Soutar, 2001; Teke, Cengiz, Cetin, Demir, Kirkbir \& Fedai, 2012; Wang, Lo, Chi \& Yang, 2004). The multidimensional approach outperforms the unidimensional approach in capturing the complexity and richness of the construct (Ruiz, Gremler, Washburn, \& Carrión, 2010). Sweeney and Soutar's (2001) PERVAL scale represents an important step forward in the measurement of perceived value because it follows a rigorous process of developing perceived value and it allows empirical testing of the multidimensional character of the construct (Sánchez, Callarisa, Rodríguez, \& Moliner, 2006). This scale considers functional (performance/quality), monetary (price/value for money), emotional (pertaining to internal emotional and feelings) and social (pertaining to the social impact of the purchase made) dimensions (Sweeney and Soutar, 2001).

The present study adopts the PERVAL model Sweeney and Soutar (2001) proposed to measure customer perceived value of mobile internet service. However, only three value dimensions (i.e. functional, monetary, and emotional values) that are most relevant to mobile internet service experience are considered in this study. 
Functional value refers to the technical benefits customers acquire from superior network performance that is reflected by the connectivity, stability, speed, and responsiveness of the mobile internet service (Chuah, Marimuthu, \& Ramayah, 2014). Monetary value relates to the monetary benefits customers acquire by subscribing to the mobile internet service of a particular service provider (Lim, Widdows, \& Park, 2006). Finally, emotional value pertains to the customers' perception of fun, pleasure, and enjoyment gained by subscribing to the mobile internet service of a particular service provider (Chuah et al., 2014).

\section{Customer Loyalty}

The concept of customer loyalty occupies a central place in marketing and it also is among the most enduring assets possessed by a company (Kandampully, Zhang, \& Bilgihan, 2015; Toufaily, Richard, \& Perrien, 2013). Creating and maintaining loyal customers is increasingly seen to be crucial to the success of firms, with the growing realisation that acquiring new customers is five times more expensive than retaining the existing ones (Özgener \& İraz, 2006; Too, Souchon, \& Thirkell, 2001). Loyal customers are less costly to serve, less price sensitive, and less influenced by competitors' attacks (Ganesh, Arnold, \& Reynolds, 2000; Reichheld $\&$ Teal, 1996). Furthermore, loyal customers are willing to pay premium prices, spend more, and provide new referrals through positive word-of-mouth $\left(\mathrm{O}^{\prime} \mathrm{Brien}\right.$ \& Jones, 1995; Reichheld \& Teal, 1996; Reinartz \& Kumar, 2002). All of these desired behaviours will ultimately lead to steady cash flows and increased revenues for a business (Aksoy, 2013). The literature took three distinctive approaches to measure customer loyalty: behavioural, attitudinal, and composite (Bowen \& Chen, 2001; Zins, 2001). The behavioural measurements strictly look at repeat purchase behaviour (i.e. expressed in terms of revealed behaviour, such as the proportion, sequence, and probability of purchase) of a consumer towards a particular brand as an indicator of loyalty (Yanamandram, \& White, 2006). In contrast, the attitudinal approach uses an individual's psychological disposition, such as stated preferences, favourable attitudes, and sense of goodwill toward a brand to gauge customer loyalty (Evanschitzky, Iyer, Plassmann, Niessing, \& Meffert, 2006; Kim, Park, \& Jeong, 2004; Mellens, Dekimpe, \& Steenkamp, 1996). Finally, the composite approach should provide a better prediction for "true" loyalty because it combines the behavioural and attitudinal measurements, and assesses loyalty according to customers' product preferences, propensity of brand-switching, frequency of purchase, recency of purchase and total amount of purchase (Bowen \& McCain, 2015). 


\section{CONCEPTUAL FRAMEWORK AND HYPOTHESES}

\section{The Relationships among Perceived Firm Marketing Innovation Initiatives, Customer Perceived Value and Customer Loyalty}

A firm's long-term viability in hypercompetitive markets depends on how well it embodies its creative ideas in marketing strategies that manifest in innovative products that fulfil customers' changing needs and expectations (Im, Montoya, \& Workman, 2013). Innovation allows differentiating the firm's offering by creating advantages that customers really appreciate and value (van Riel \& Allard, 2012). Hence, the competitive advantage of successful firms can be explained with a logic wherein perceived firm marketing innovation initiatives (PFMII) contributes to customer value, resulting in increased satisfaction and behavioural intentions, eventually escalating loyalty that manifests itself in enhanced profitability (Kim et al., 2015; Kunz, Schmitt, \& Meyer, 2011; Naidoo, 2010, Stock, 2011; Williams \& Soutar, 2009). More recently, Hwang and Hyun (2015) examined the role of perceived firm innovativeness based on data from 315 cruise travellers, and found that perceived firm innovativeness plays an important role in forming cruise travellers' experience related to education, entertainment, aesthetics, and escapism. In addition, cruise travellers' experience was found to have a significant positive effect on perceived luxury value. Kim et al. (2015) also verified that perceived brand benefits (in instrumental and symbolic) through innovation enables mobile phone firms to create superior value for customers, which in turn can increase customer satisfaction.

On the basis of the preceding discussion and empirical evidence, we postulate that PFMII will significantly influence customers' quality and price perceptions (functional and monetary values) that will, in turn, influence their affective aspect of value (emotional value). The enhancement of customer value perceptions (e.g. functional, monetary, and emotional values) will ultimately lead to customer loyalty. In addition, functional and monetary values are expected to exert mediating effects on the relationship between PFMII and customer loyalty.

H1: PFMII positively impacts functional value.

H2: PFMII positively impacts monetary value.

H3: Functional value positively impacts emotional value.

H4: Monetary value positively impacts emotional value.

H5: Functional value positively impacts customer loyalty.

H6: Emotional value positively impacts customer loyalty. 
H7: Monetary value positively impacts customer loyalty.

H8: Functional value mediates the relationship between PFMII and customer loyalty.

H9: Monetary value mediates the relationship between PFMII and customer loyalty.

\section{The Moderating Effect of Switching Experience on the Relationship between Perceived Firm Marketing Innovation Initiatives on Functional and Monetary Values}

Switching experience is defined as the extent to which customers switched between service providers in the past (Burnham, Frels, \& Mahajan, 2003). Customers with greater experience in switching might have a higher set of available alternatives and they know what outcomes can be expected in other service providers (Ganesh et al., 2000). Therefore, a customer with a broad product or service experience might develop a different standard of comparison compared to consumers with a narrow experience: they have a higher level of expectation, more demanding and difficult to satisfy (Matzler et al., 2015). As Ganesh et al. (2000) pointed out, the expectations held by experienced switchers will at least be at the level previously held, and higher expectations always lead to lower satisfaction judgement. Accordingly, we expect switching experience to moderate the relationship between PFMII and customer perceived value (e.g. functional and monetary values). Based on these arguments we propose:

H10: The relationship between PFMII and functional value is moderated by switching experience,such that the relationship is weaker for those with switching experience (switchers).

H11: The relationship between PFMII and monetary value is moderated by switching experience,such that the relationship is weaker for those with switching experience (switchers).

In summary, the preceding section presents the research hypotheses developed for this study. Figure 1 below displays the conceptual framework guiding this study. The framework depicts the relationship among PFMII, customer perceived value, customer loyalty, and switching experience. As can be seen, both functional and monetary values serve as the mediators in the relationship between PFMII and customer loyalty, whereas switching experience (switchers versus non-switchers) acts as the moderator in the relationship between PFMII and two perceived value dimensions (e.g. functional and monetary values). Figure 1 summarises the hypothesised relationships and their directions. 


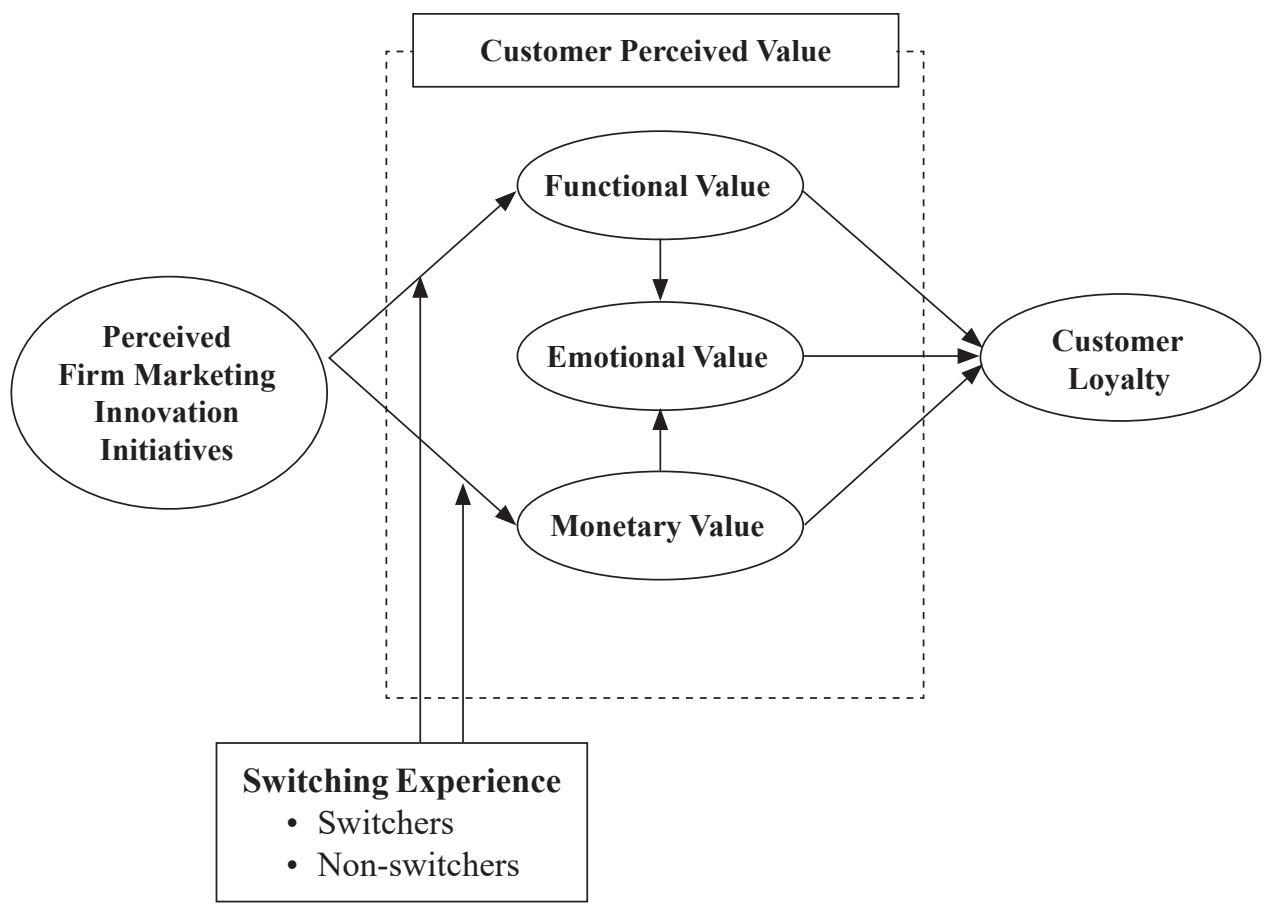

Figure 1. Proposed conceptual framework

\section{RESEARCH METHODOLOGY}

\section{Measurement Scales}

All research constructs were operationalised and measured using well-established multiple-item scales adapted from previous studies, making only minor changes of wording to suit them to the target context. Items for PFMII were adapted from Banff (2006), items for functional value were adapted from Jeon (2008) and Chae and Kim (2001), items for monetary value were adapted from Sweeney and Soutar (2001) and Xie, Xiong, Chen, and $\mathrm{Hu}$ (2011), items for emotional value were adapted from Sweeney and Soutar (2001), and items for customer loyalty were adapted from Aydin and Özer (2005).

\section{Data Collection and Sample Profile}

A self-administered questionnaire was utilised in order to collect data from Generation Y (18-34 years old) (Bruwer, Saliba, \& Miller, 2011) who subscribed to the post-paid mobile plans offered by the four main mobile network operators (i.e. Maxis, Celcom, DiGi, and U Mobile) in Malaysia. A total of 470 questionnaires 
were distributed from August to November 2013. Of the 452 questionnaires received, 417 were valid and usable for data analysis. Out of a sample of 417, $50.8 \%$ were female, $61.2 \%$ were between the ages of 25 and 34 , and $70.2 \%$ hold a bachelor degree or higher. Almost half of the respondents were professionals, managers, executives or businessmen (48.2\%), and 43.6\% earned an annual household income of RM36,000 or above. In terms of mobile service subscriptions, $80 \%$ of the respondents had a principal line, $70.5 \%$ paid their own mobile phone bills, and around $73.0 \%$ had monthly phone bills of RM150 or less. With regard to the experience in switching, $37.4 \%$ respondents reported that they had changed their mobile operators in the past, whereas $62.6 \%$ responded that they had never changed their mobile operators before.

\section{DATA ANALYSIS AND RESULTS}

The data was analysed using the Partial Least Square Structural Equation Modelling (PLS-SEM) through the SmartPLS 2.0 M3 software (Ringle, Wende, $\&$ Will, 2005). This statistical technique allows researchers to simultaneously test a set of interrelated hypotheses by evaluating the relationships among multiple endogenous and exogenous variables in a research model (Gefen, Straub, \& Boudreau, 2000). The proposed research model was assessed using the two-step approach where the measurement model was first tested followed by the structural model assessment (Anderson \& Gerbing, 1988).

In the first stage, the validity and reliability of the measurement model was evaluated through convergent validity, discriminant validity, and reliability of the item measures used. As Table 1 shows, the items loading of all constructssurpassed the minimum required cut-off value of 0.40 (Hair, Hult, Ringle, \& Sarstedt, 2013), and the AVEs of all constructs were well above the 0.50 threshold (Fornell \& Larcker, 1981), signifying a sufficient level of convergent validity. In examining the discriminant validity, we employed the Fornell-Larcker criterion (Fornell \& Larcker, 1981), whereby the square root of the AVE values was compared against the correlations of other constructs. Discriminant validity of all constructs was supported as the square root of the AVE for each construct was greater than its highest correlation with any other constructs (Table 2). Also, the composite reliability of all constructs was greater than the recommended level of 0.708 (Hair et al., 2013), providing strong support for construct reliability.

In the second stage, the structural model was assessed in terms of the collinearity among the set of constructs, coefficient of determination $\left(R^{2}\right.$ value) and significance of path coefficients, and predictive relevance $\left(Q^{2}\right)$. To assess collinearity, all the 
Stephanie Hui-Wen Chuah et al.

Table 1

Results of the Measurement Model

\begin{tabular}{|c|c|c|c|c|}
\hline Model Construct & Measurement Item & Loading & $\mathrm{CR}^{\mathrm{a}}$ & $\mathrm{AVE}^{\mathrm{b}}$ \\
\hline \multirow{3}{*}{$\begin{array}{l}\text { Perceived firm marketing } \\
\text { innovation initiatives (PFMII) }\end{array}$} & PFMII1 & 0.920 & 0.944 & 0.849 \\
\hline & PFMII2 & 0.930 & & \\
\hline & PFMII3 & 0.914 & & \\
\hline \multirow[t]{4}{*}{ Functional value (FV) } & FV1 & 0.838 & 0.902 & 0.698 \\
\hline & FV2 & 0.843 & & \\
\hline & FV3 & 0.817 & & \\
\hline & FV4 & 0.843 & & \\
\hline \multirow[t]{5}{*}{ Emotional Value (EV) } & EV1 & 0.908 & 0.959 & 0.825 \\
\hline & EV2 & 0.892 & & \\
\hline & EV3 & 0.891 & & \\
\hline & EV4 & 0.933 & & \\
\hline & EV5 & 0.916 & & \\
\hline \multirow[t]{4}{*}{ Monetary Value (MV) } & MV1 & 0.942 & 0.932 & 0.778 \\
\hline & MV2 & 0.945 & & \\
\hline & MV3 & 0.937 & & \\
\hline & MV4 & 0.674 & & \\
\hline \multirow[t]{5}{*}{ Customer Loyalty (CL) } & CL1 & 0.871 & 0.936 & 0.745 \\
\hline & CL2 & 0.909 & & \\
\hline & CL3 & 0.766 & & \\
\hline & CL4 & 0.880 & & \\
\hline & CL5 & 0.883 & & \\
\hline
\end{tabular}

${ }^{a}$ Composite reliability $(\mathrm{CR})=($ square of the summation of the factor loadings $) /$ \{ (square of the summation of the factor loadings) + (square of the summation of the error variances) $\}$

${ }^{\mathrm{b}}$ Average variance extracted $(\mathrm{AVE})=$ (summation of the square of the factor loadings $) /\{$ (summation of the square of the factor loadings $)+$ (summation of the error variances) $\}$

Table 2

Results of the Discriminant Validity Analysis

\begin{tabular}{lccccc}
\hline & CL & EV & FV & MV & PFMII \\
\hline CL & $\mathbf{0 . 8 6 3}$ & & & & \\
EV & 0.561 & $\mathbf{0 . 9 0 8}$ & & & \\
FV & 0.581 & 0.621 & $\mathbf{0 . 8 3 5}$ & & \\
MV & 0.496 & 0.609 & 0.516 & $\mathbf{0 . 8 8 2}$ & \\
PFMII & 0.627 & 0.500 & 0.475 & 0.485 & $\mathbf{0 . 9 2 1}$ \\
\hline
\end{tabular}

Note: Diagonals (in bold) represent the square root of average variance extracted (AVE) while the off-diagonals represent the construct correlations. 
predictor variables (e.g. PFMII, functional value, emotional value, and monetary value) were regressed against customer loyalty in the SPSS software (Version 19). The results showed that the variance inflation factor (VIF) values of all constructs ranged from 1.485 to 2.055 , well below the common cut-off threshold of 5 (Hair et al., 2013), suggesting that the multicollinearity was unlikely a threat to the parameter estimates of this study. Next, the significance of path coefficients was examined by performing the bootstrapping procedure of 5,000 resamples (Hair et al., 2013). As Table 3 shows, PFMII had significance positive relationships withfunctional $(\beta=0.475, t=12.005, p<0.01)$ and monetary values $(\beta=0.485$, $t=11.768, p<0.01)$. Both functional andmonetary values in turn influenced emotional value with $\beta=0.417, t=11.080, p<0.01$ and $\beta=0.394, t=10.467$, $p<0.01$ respectively. The results also indicated that all perceived value dimensions (i.e. functional, emotional and monetary value) significantly influenced customer loyalty, collectively explaining $42.1 \%$ of its variance. Notably, functional value had the strongest effect on customer loyalty $(\beta=0.341, t=6.304, p<0.01)$, followed by emotional value $(\beta=0.246, t=4.034, p<0.01)$ and monetary value $(\beta=0.170$, $t=3.220, p<0.01)$. Therefore, all hypotheses from $\mathrm{H} 1$ to H7were supported.

Table 3

Hypotheses Testing (Direct Effects)

\begin{tabular}{cccccl}
\hline Hypothesis & Relationship & $\begin{array}{c}\text { Path Coefficient } \\
(\beta)\end{array}$ & $\begin{array}{c}\text { Standard } \\
\text { Error }\end{array}$ & t-value & Decision \\
\hline H1 & PFMII -> FV & 0.475 & 0.040 & $12.005^{* * *}$ & Supported \\
H2 & PFMII -> MV & 0.485 & 0.041 & $11.768^{* *}$ & Supported \\
H3 & FV -> EV & 0.417 & 0.038 & $11.080^{* *}$ & Supported \\
H4 & MV -> EV & 0.394 & 0.042 & $10.467^{* *}$ & Supported \\
H5 & FV -> CL & 0.341 & 0.054 & $6.304^{* *}$ & Supported \\
H6 & EV -> CL & 0.246 & 0.061 & $4.034^{* *}$ & Supported \\
H7 & MV - > CL & 0.170 & 0.053 & $3.220^{* *}$ & Supported \\
\hline
\end{tabular}

Note. ${ }^{* *} p<0.01,{ }^{*} p<0.05$ (based on one-tailed test)

After testing the direct effects, we proceeded to examine the mediation hypotheses using the guideline proposed by Preacher and Hayes (2008). In order to verify the mediating effects of functional and monetary values on the relationship between PFMII and customer loyalty, we employed the bootstrapping method to obtain the standard error of path coefficient between $a$ and $b$. The mediating effect is statistically significant if the t-value $(\mathrm{a} * \mathrm{~b} /$ standard error of $\mathrm{a} * \mathrm{~b})$ exceeds 1.96 (at $p<0.05$ (two-tailed)). As Table 4 shows, the indirect effect of PFMII on customer loyalty (through functional and monetary values) was significant with $\beta=0.162, \mathrm{t}=5.114, p<0.01$ and $\beta=0.082, \mathrm{t}=2.826, p<0.01$ respectively. 
Furthermore, the indirect effects 0.162 [95\% bootstrapped confidence intervals: $($ Lower Limit $=0.100$, Upper Limit $=0.224)]$ and $0.082[95 \%$ bootstrapped confidence intervals: $($ Lower Limit $=0.025$, Upper Limit $=0.139)$ ] did not straddle a zero in below, implying that both functional and monetary values exerted mediating effects on the relationship between PFMII and customer loyalty. This lends support to $\mathrm{H} 8$ and $\mathrm{H} 9$.

Table 4

Hypotheses Testing (Mediating Effects)

\begin{tabular}{|c|c|c|c|c|c|c|c|}
\hline \multirow[t]{2}{*}{ Hypothesis } & \multirow[t]{2}{*}{ Relationship } & \multirow{2}{*}{$\begin{array}{c}\text { Path } \\
\text { Coefficient } \\
(\beta) \\
(a * b)\end{array}$} & \multirow{2}{*}{$\begin{array}{l}\text { Standard } \\
\text { Error }\end{array}$} & \multirow[t]{2}{*}{ t-value } & \multicolumn{2}{|c|}{$\begin{array}{c}\text { Bootstrapping } \\
\text { Percentile } 95 \% \text { CI }\end{array}$} & \multirow{2}{*}{ Decision } \\
\hline & & & & & Lower & Upper & \\
\hline $\mathrm{H} 8$ & PFMII $->$ FV $->$ CL & 0.162 & 0.031671 & $5.114 * *$ & 0.100 & 0.224 & Supported \\
\hline H9 & PFMII $->$ MV $->C L$ & 0.082 & 0.029177 & $2.826 * *$ & 0.025 & 0.139 & Supported \\
\hline
\end{tabular}

Note: $* * p<0.01, * p<0.05$ (based on two-tailed test)

$\mathrm{CI}=$ Confidence Intervals

To check the moderating effect of switching experience, we conducted a multigroup analysis, which tests the coefficient difference between switchers and nonswitchers. This study used the following equation introduced by Hair et al. (2013).

$$
t=\frac{\left|p^{(1)}-p^{(2)}\right|}{\sqrt{\frac{\left(n^{(1)}-1\right)^{2}}{\left(n^{(1)}+n^{(2)}-2\right)} \cdot \operatorname{se}\left(p^{(1)}\right)^{2}+\frac{\left(n^{(2)}-1\right)^{2}}{\left(n^{(1)}+n^{(2)}-2\right)} \cdot \operatorname{se}\left(p^{(2)}\right)^{2} \cdot \sqrt{\frac{1}{n^{(1)}}+\frac{1}{n^{(2)}}}}}
$$

Table 5 provides the results of multi-group analysis, which includes the path coefficients, standard error of the coefficients, and $t$-values. As can be seen, the effects of PFMII on both functional and monetary valueswere not significantly different across the two groups $(\beta=0.113, t=1.371, p>0.05$ and $\beta=0.087$, $t=1.027, p>0.05$ ), thus indicating thatswitching experience did not exert a moderating effect on the relationship between PFMII and customer perceived value (i.e. both functional and monetary). Therefore, H10 and H11 were not supported.

Finally, we assessed the predictive capacity of the research model by checking the Stone-Geisser's $Q^{2}$ value (Geisser, 1974; Stone, 1974). According to the rule of thumb, a $Q^{2}$ greater than 0 (zero) implies that the model has predictive relevance, whereas a $Q^{2}$ less than 0 (zero) signifies that the model lacks predictive relevance 
Table 5

Results of the Multi-Group Analysis

\begin{tabular}{|c|c|c|c|c|c|c|c|c|c|c|}
\hline & \multicolumn{3}{|c|}{$\begin{array}{l}\text { Group 1: } \\
\text { Switchers }\end{array}$} & \multicolumn{3}{|c|}{$\begin{array}{c}\text { Group 2: } \\
\text { Non-Switchers }\end{array}$} & \multicolumn{4}{|c|}{ Group 1 vs. Group 2} \\
\hline & $\mathrm{p}^{(1)}$ & $\operatorname{se}\left(\mathrm{p}^{(1)}\right)$ & t-value & $\mathrm{p}^{(2)}$ & $\operatorname{se}\left(\mathrm{p}^{(2)}\right)$ & t-value & {$\left[\mathrm{p}^{(1)}-\mathrm{p}^{(2)}\right]$} & t-value & $\begin{array}{c}\text { Significance } \\
\text { Level }\end{array}$ & $\mathrm{p}$ value \\
\hline PFMII -> FV & 0.540 & 0.062 & 8.717 & 0.427 & 0.052 & 8.226 & 0.113 & 1.371 & n.s. & 0.171 \\
\hline \multirow[t]{2}{*}{ PFMII -> MV } & 0.546 & 0.060 & 9.031 & 0.459 & 0.055 & 8.272 & 0.087 & 1.027 & n.s. & 0.305 \\
\hline & & 156 & & & 261 & & & & & \\
\hline
\end{tabular}

Notes: $p^{(1)}$ and $p^{(2)}$ are path coefficient of Group 1 and Group 2, respectively; $\operatorname{se}\left(p^{(1)}\right)$ and $\operatorname{se}\left(p^{(2)}\right)$ are the standard error of $p^{(1)}$ and $p^{(2)}$, respectively.

$* * p<0.01,{ }^{*} p<0.05$, n.s. $=$ non-significant

(Fornell \& Cha, 1994). By using the blindfolding procedure for an omission distance of 5 , we obtained a $Q^{2}$ value of 0.306 for customer loyalty. This signifies that the research model has good predictive relevance.

\section{DISCUSSION AND IMPLICATIONS}

This study proposes and tests an integrative conceptual framework of PFMII, customer perceived value, customer loyalty, and switching experience. Previous customer value studies have predominantly focused on the price and quality of products as the value antecedents (see, for example, Cronin, Brady, \& Hult, 2000; Jiang, Jun, \& Yang, 2015; Oh, 1999). However, in an increasingly hostile business environment, competitive firms no longer keep offering run-of-mill products or just vie on traditional grounds, such as price and quality (Khin, Ahmad, \& Ramayah, 2010). For mobile telecommunications service companies, especially, the inevitable trend is to continually innovate and develop value-enhanced products in order to outperform competition. To the best of our knowledge, our study is among the first to examine and empirically verify the linkage between PFMII and customer perceived value in the context of mobile internet service. From a theoretical perspective, the present study successfully extends Sweeney and Soutar's (2001) PERVAL model by incorporating PFMII as the key precursor of customer perceived value. Furthermore, in contrast to previous studies that examined the effect of innovation on customer loyalty (e.g. Lee, 2010; Nemati, Khan, \& Iftikhar, 2010) or the effect of perceived value on customer loyalty (e.g. Eid, 2013; Jiang et al., 2015), we theoretically assert and empirically confirm that customer perceived value (i.e. both functional and monetary) are the mediators in the relationship between PFMII and customer loyalty in the mobile internet service setting. This is an important contribution, as it clarifies a mechanism through which PFMII is translated into customer loyalty. 
This research also has several practical implications for mobile operators. This study verifies that embarking on marketing innovation initiatives is a viable way for mobile telecommunications service companies to create superior customer value, thus helping them enlarge their loyal customer base. The study's findings also revealed that engaging in marketing innovation initiatives will improve customers' quality and price perceptions (functional and monetary values) that will in turn, enhance perceived emotional value by making their mobile internet usage experience more enjoyable. However, since new products in the mobile services market can be easily imitated by competitors in a very short space of time, the duration of the competitive advantage through innovation will be limited in time (van Riel \& Allard, 2012). In order to maintain sustainable market leadership, mobile operators need to out-innovate the competition continuously: through creative thinking and anticipating customers' prospective needs they can offer more and better value to their customers (Kandampully \& Duddy, 1999; van Riel \& Allard, 2012).

Although the results indicated a lack of significant difference in the effect of PFMII on both functional and monetary values between switchers and non-switchers, PFMII had a greater effect on perceived functional and monetary values for customers with switching experience. This unexpected finding can be explained, at least in part, by the assumption that most switchers are dissatisfied with their previous mobile operators. Customers with poor prior experience will initiate a new business relationship with a reduced comparison level and they will exhibit a higher level of satisfaction relative to those who experienced relatively little change in their comparison level (Ganesh et al., 2000). This explains why switchers will have a greater value perception than non-switchers. Summing up, mobile operators are advised to invest in marketing innovation initiatives because it could be a "killing two birds with one stone" strategy: it helps firms retain existing customers (non-switchers) and in the meantime, gain entirelynew customers (switchers) through the creation of superior value.

As with all studies, this study has some limitations. Firstly, our survey includes only Generation Y post-paid mobile internet users. Future research should include samples from other generational cohorts (e.g. Generation X and Baby Boomers) or types of plan (e.g. prepaid) to enhance external validity. Secondly, as this study employs a cross-sectional design, which does not involve investigation of cause and effect relationships, the results can only imply the association between PFMII, customer perceived value, customer loyalty, and switching experience rather than causal relationships. Finally, this study includes loyalty intention, which is only a tentative measure of behavioural loyalty (Oliva, Oliver, \& MacMillan, 1992), as 
the final dependent variable. However, it is believed that actual loyal behaviour may serve as a better outcome variable to increase the internal validity of the conceptual framework and avoid common method bias. Therefore, future studies should include objective behavioural data (e.g. lifetime duration and average monthly bill) to validate the conceptual framework.

\section{REFERENCES}

Aksoy, L. (2013). How do you measure what you can't define? The current state of loyalty measurement and management. Journal of Service Management, 24(4), 356-381. http://dx.doi.org/10.1108/JOSM-01-2013-0018

Anderson, J. C., \& Gerbing, D. W. (1988). Structural equation modeling in practice: A review and recommended two-step approach. Psychological Bulletin, 103(3), 411-423. http://dx.doi.org/10.1037/0033-2909.103.3.411

Andrews, J., \& Smith, D. C. (1996). In search of the marketing imagination: Factors affecting the creativity of marketing programs for mature products. Journal of Marketing Research, 33(2), 174-187.

Aydin, S., \& Özer, G. (2005). The analysis of antecedents of customer loyalty in the Turkish mobile telecommunication market. European Journal of Marketing, 39(7/8), 910-925. http://dx.doi.org/10.1108/03090560510601833

Banff, A. (2006). The mixed effects of brand innovativeness and consumer innovativeness on attitude towards the brand. Paper presented at the Administractive Sciences Association of Canada (ASAC), Calgary, Canada.

Bloch, C. (2007). Assessing recent developments in innovation measurement: The third edition of the Oslo Manual. Science \& Public Policy, 34(1), 23-34. http://dx.doi. org $/ 10.3152 / 030234207 X 190487$

Boksberger, P. E., \& Melsen, L. (2011). Perceived value: A critical examination of definitions, concepts and measures for the service industry. Journal of Services Marketing, 25(3), 229-240. http://dx.doi.org/10.1108/08876041111129209

Bowen, J. T., \& McCain, S. L. C (2015). Transitioning loyalty programs: A commentary on "The relationship between customer loyalty and customer satisfaction". International Journal of Contemporary Hospitality Management, 27(3), 415430. http://dx.doi.org/10.1108/IJCHM-07-2014-0368

Bowen, J. T., \& Chen, S. L. (2001). The relationship between customer loyalty and customer satisfaction. International Journal of Contemporary Hospitality Management, 13(5), 213-217. http://dx.doi.org/10.1108/09596110110395893

Bruwer, J., Saliba, A., \& Miller, B. (2011). Consumer behaviour and sensory preference differences: Implications for wine product marketing. Journal of Consumer Marketing, 28(1), 5-18. http://dx.doi.org/10.1108/07363761111101903

Burnham, T. A., Frels, J. K., \& Mahajan, V. (2003). Consumer switching costs: A typology, antecedents, and consequences. Journal of the Academy of Marketing Science, 31(2), 109-126. http://dx.doi.org/10.1177/0092070302250897 
Caruana, A., \& Fenech, N. (2005). The effect of perceived value and overall satisfaction on loyalty: A study among dental patients. Journal of Medical Marketing, 5(3), 245-255. http://dx.doi.org/10.1057/palgrave.jmm.5040236

Chae, M., \& Kim, J. (2001). Information quality for mobile internet services: A theoretical model with empirical validation. Paper presented at the International Conference on Information Systems (ICIS).

Chen, A. C. H. (2001). Using free association to examine the relationship between the characteristics of brand associations and brand equity. Journal of Product \& Brand Management, 10(7), 439-451. http://dx.doi.org/10.1108/10610420110410559

Chen, P. T., \& Hu, H. H. (2010). How determinant attributes of service quality influence customer-perceived value: An empirical investigation of the Australian coffee outlet industry. International Journal of Contemporary Hospitality Management, 22(4), 535-551. http://dx.doi.org/10.1108/09596111011042730

Chen, W. (2013). Perceived value in community supported agriculture (CSA): A preliminary conceptualization, measurement, and nomological validity. British Food Journal, 115(10), 1428-1453. http://dx.doi.org/10.1108/BFJ-01-2011-0013

Chen, Y. S., \& Chang, C. H. (2012). Enhance green purchase intentions: The roles of green perceived value, green perceived risk, and green trust. Management Decision, 50(3), 502-520. http://dx.doi.org/10.1108/00251741211216250

Chuah, H. W., Marimuthu, M., \& Ramayah, T. (2014). The effect of perceived value on the loyalty of Generation Y mobile internet subscribers: A proposed conceptual framework. Procedia-Social and Behavioral Sciences, 130, 532-541. http:// dx.doi.org/10.1016/j.sbspro.2014.04.062

Cronin, J. J., Brady, M. K., \& Hult, G. T. M. (2000). Assessing the effects of quality, value, and customer satisfaction on consumer behavioral intentions in service environments. Journal of Retailing, 76(2), 193-218. http://dx.doi.org/10.1016/ S0022-4359(00)00028-2

Danneels, E., \& Kleinschmidtb, E. J. (2001). Product innovativeness from the firm's perspective: Its dimensions and their relation with project selection and performance. Journal of Product Innovation Management, 18(6), 357-373. http:// dx.doi.org/10.1016/S0737-6782(01)00109-6

Eid, R. (2013). Integrating Muslim customer perceived value, satisfaction, loyalty and retention in the tourismindustry: An empirical study. International Journal of Tourism Research, 1-12. http://dx.doi.org/10.1002/jtr.1982

Evanschitzky, H., Iyer, G. R., Plassmann, H., Niessing, J., \& Meffert, H. (2006). The relative strength of affective commitment in securing loyalty in service relationships. Journal of Business Research, 59(12), 1207-1213. http://dx.doi.org/10.1016/j. jbusres.2006.08.005

Fornell, C., \& Cha, J. (1994). Partial least squares. In R. P. Bagozzi (Ed.), Advanced methods of marketing research (pp. 52-78). Cambridge, MA: Blackwell Business.

Fornell, C., \& Larcker, D. F. (1981). Evaluating structural equation models with unobservable variables and measurement error. Journal of Marketing Research, 18(1), 39-50. http://dx.doi.org/10.2307/3151312 
Ganesh, J., Arnold, M. J., \& Reynolds, K. E. (2000). Understanding the customer base of service providers: An examination of the differences between switchers and stayers. Journal of Marketing, 64(3), 65-87. http://dx.doi.org/10.1509/ jmkg.64.3.65.18028

Gefen, D., Straub, D., \& Boudreau, M. C. (2000). Structural equation modeling and regression: Guidelines for research practice. Communications of the Association for Information Systems, 4(1), 1-78.

Gehlhar, M. J., Regmi, A., Stefanou, S. E., \& Zoumas, B. L. (2009). Brand leadership and product innovation as firm strategies in global food markets. Journal of Product \& Brand Management, 18(2), 115-126. http://dx.doi. org/10.1108/10610420910949013

Geisser, S. (1974). A predictive approach to the random effect model. Biometrika, 61(1), 101-107. http://dx.doi.org/10.1093/biomet/61.1.101

Gunday, G., Ulusoy, G., Kilic, K., \& Alpkan, L. (2011). Effects of innovation types on firm performance. International Journal of Production Economics, 133(2), 662-676. http://dx.doi.org/10.1016/j.ijpe.2011.05.014

Hair Jr, J. F., Hult, G. T. M., Ringle, C. M., \& Sarstedt, M. (2013). A primer on partial least squares structural equation modeling (PLS-SEM). Thousand Oaks, California: Sage Publications, Inc.

Holbrook, M. B. (1994). The nature of customer value: An axiology of services in the consumption experience. In R. T. Rust \& R. L. Oliver (Eds.), Service quality new directions in theory and practice. Thousand Oaks, California: Sage Publications, Inc. http://dx.doi.org/10.4135/9781452229102.n2

Huang, R. (2013). Mobile internet revenue to exceed fixed broadband globally by 2014 . Retrieved from http://www.zdnet.com/mobile-internet-revenue-to-exceedfixedbroadband-globally-by-2014-7000016395/

Hult, G. T. M., Hurley, R. F., \& Knight, G. A. (2004). Innovativeness: Its antecedents and impact on business performance. Industrial Marketing Management, 33(5), 429-438. http://dx.doi.org/10.1016/j.indmarman.2003.08.015

Hwang, J., \& Hyun, S. S. (2015). Perceived firm innovativeness in cruise travelers' experience and perceived luxury value: The moderating effect of advertising effectiveness. Asia Pacific Journal of Tourism Research, 1-28. http://dx.doi.org/1 0.1080/10941665.2015.1016051

Im, S., Montoya, M. M., \& Workman, J.P.(2013). Antecedents and consequences of creativity in product innovation teams. Journal of Product Innovation Management, 30(1), 170-185. http://dx.doi.org/10.1111/j.1540-5885.2012.00887.x

Jeon, S. (2008). Mobile internet service: Assessment of quality and satisfaction from the customer's perspective (Doctoral Dissertation). Retrieved from ProQuest Dissertations and Theses Database. (UMI No. 3315206).

Jiang, L., Jun, M., \& Yang, Z. (2015). Customer-perceived value and loyalty: How do key service quality dimensions matter in the context of B2C e-commerce? Service Business, 1-17.

Jiang, P. (2009). Consumer adoption of mobile internet services: An exploratory study. Journal of Promotion Management, 15(3), 418-454. http://dx.doi. org/10.1080/10496490903196213 
Johne, A. (1999). Successful market innovation. European Journal of Innovation Management, 2(1), 6-11. http://dx.doi.org/10.1007/978-3-642-58427-5_15

Kandampully, J., \& Duddy, R. (1999). Competitive advantage through anticipation, innovation and relationships. Management Decision, 37(1), 51-56. http://dx.doi. org/10.1108/00251749910252021

Kandampully, J., Zhang, T., \& Bilgihan, A. (2015). Customer loyalty: a review and future directions with a special focus on the hospitality industry. International Journal of Contemporary Hospitality Management, 27(3), 379-414. http://dx.doi. org/10.1108/IJCHM-03-2014-0151

Khalifa, A. S. (2004). Customer value: A review of recent literature and an integrative configuration. Management Decision, 42(5), 645-666. http://dx.doi. org/10.1108/00251740410538497

Khin, S., Ahmad, N. H., \& Ramayah, T. (2010). Product innovation among ICT technopreneurs in Malaysia. Business Strategy Series, 11(6), 397-406. http://dx.doi.org/10.1108/17515631011093106

Kim, J., Kim, K. H., Garrett, T. C., \& Jung, H. (2015). The contributions of firm innovativeness to customer value in purchasing behavior. Journal of Product Innovation Management, 32(2), 201-213. http://dx.doi.org/10.1111/jpim.12173

Kim, M. K., Park, M. C., \& Jeong, D. H. (2004). The effects of customer satisfaction and switching barrier on customer loyalty in Korean mobile telecommunication services. Telecommunications policy, 28(2), 145-159. http://dx.doi.org/10.1016/j. telpol.2003.12.003

Kunz, W., Schmitt, B., \& Meyer, A. (2011). How does perceived firm innovativeness affect the consumer? Journal of Business Research, 64(8), 816-822. http://dx.doi. org/10.1016/j.jbusres.2010.10.005

Lai, A. W. (1995). Consumer values, product benefits and customer value: A consumption behavior approach. Advances in Consumer Research, 22(1), 381-388.

Lam, S. Y., \& Shankar, V. (2014). Asymmetries in the effects of drivers of brand loyalty between early and late adopters and across technology generations. Journal of Interactive Marketing, 28(1), 26-42. http://dx.doi.org/10.1016/j. intmar.2013.06.004

Lee, C. K., Yoon, Y. S., \& Lee, S. K. (2007). Investigating the relationships among perceived value, satisfaction, and recommendations: The case of the Korean DMZ. Tourism Management, 28(1), 204-214. http://dx.doi.org/10.1016/j.tourman.2005.12.017

Lee, J. W. (2010). Critical factors that establish customer loyalty to mobile communications service providers: Empirical evidence from the United States. Paper presented at the Allied Academies International Conference, Las Vegas, USA.

Lim, H., Widdows, R., \& Park, J. (2006). M-loyalty: Wining strategies for mobile carriers. Journal of Consumer Marketing, 23(4), 208-218. http://dx.doi. org/10.1108/07363760610674338

Lin, C. H., Sher, P. J., \& Shih, H. Y. (2005). Past progress and future directions in conceptualizing customer perceived value. International Journal of Service Industry Management, 16(4), 318-336. http://dx.doi.org/10.1108/095642305 10613988 
Matzler, K., Strobl, A., Thurner, N., \& Füller, J. (2015). Switching experience, customer satisfaction, and switching costs in the ICT industry. Journal of Service Management, 26(1), 117-136. http://dx.doi.org/10.1108/JOSM-04-2014-0101

Mayr, T., \& Zins, A. H. (2012). Extensions on the conceptualization of customer perceived value: insights from the airline industry. International Journal of Culture, Tourism and Hospitality Research, 6(4), 356-376. http://dx.doi. org/10.1108/17506181211265086

Mellens, M., Dekimpe, M. G., \& Steenkamp, J.-B. E. M. (1996). A review of brand loyalty measures in marketing. Tijdschrift voor Economie en Management, 41(4), 507533.

Morgan, R. M., \& Hunt, S. D. (1994). The commitment-trust theory of relationship marketing. Journal of Marketing, 58(3), 20-38. http://dx.doi.org/10.2307/1252308

Naidoo, V. (2010). Firm survival through a crisis: The influence of market orientation, marketing innovation and business strategy. Industrial Marketing Management, 39(8), 1311-1320. http://dx.doi.org/10.1016/j.indmarman.2010.02.005

Nemati, A. R., Khan, K., \& Iftikhar, M. (2010). Impact of innovation on customer satisfaction and brand loyalty: A study of mobile phones users in Pakistan. European Journal of Social Sciences, 16(2), 299-206.

New Straits Times. (2011, December 9). Malaysians spend RM46/month on mobile web.

O'Brien, L., \& Jones, C. (1995). Do rewards really create loyalty? Harvard Business Review, 73(3), 75-82.

OECD. (2005). Oslo manual: Guidelines for collecting and interpreting innovation data (3rd ed.).

Oh, H. (1999). Service quality, customer satisfaction, and customer value: A holistic perspective. International Journal of Hospitality Management, 18(1), 67-82. http://dx.doi.org/10.1016/S0278-4319(98)00047-4

Oliva, T. A., Oliver, R. L., \& MacMillan, I. C. (1992). A catastrophe model for developing service satisfaction strategies. Journal of Marketing, 56(3), 83-95. http://dx.doi. org/10.2307/1252298

Özgener, Ş., \& İraz, R. (2006). Customer relationship management in small-medium enterprises: The case of Turkish tourism industry. Tourism Management, 27(6), 1356-1363. http://dx.doi.org/10.1016/j.tourman.2005.06.011

Preacher, K. J., \& Hayes, A. F. (2008). Asymptotic and resampling strategies for assessing and comparing indirect effects in multiple mediator models. Behavior Research Methods, 40(3), 879-891. http://dx.doi.org/10.3758/brm.40.3.879

Reichheld, F. F., \& Teal, T. (1996). The loyalty effect: The hidden force behind growth, profits, and lasting value. Boston, Massachusetts: Harvard Business School Press.

Reinartz, W., \& Kumar, V. (2002). The mismanagement of customer loyalty. Harvard Business Review, 80(7), 86-94.

Ringle, C. M., Wende, S., \& Will, S. (2005). SmartPLS 2.0 (M3) Beta, Hamburg. Retrieved from http://www. smartpls. de.

Roostika, R. (2011). The effect of perceived service quality and trust on loyalty: Customer's perspectives on mobile internet adoption. International Journal of Innovation, Management and Technology, 2(4), 286-291. 
Roostika, R. (2012). Mobile internet acceptance among university students: A value-based adoption model. International Journal of Research in Management \& Technology (IJRMT), 2(1), 21-28.

Ruiz, D. M., Gremler, D. D., Washburn, J. H., \& Carrión, G. C. (2010). Reframing customer value in a service-based paradigm: An evaluation of a formative measure in a multiindustry, cross-cultural context. In V. E. Vinzi, W. W. Chin, J. Henseler, \& H. Wang (Eds.), Handbook of partial least squares: Concepts, methods and applications (pp. 535-566). Berlin: Springer. http://dx.doi.org/10.1007/978-3540-32827-8_24

Rust, R. T., Ambler, T., Carpenter, G. S., Kumar, V., \& Srivastava, R. K. (2004). Measuring marketing productivity: Current knowledge and future directions. Journal of Marketing, 68(4), 76-89. http://dx.doi.org/10.1509/jmkg.68.4.76.42721

Sanchez, J., Callarisa, L., Rodriguez, R. M., \& Moliner, M. A. (2006). Perceived value of the purchase of a tourism product. Tourism Management, 27(3), 394-409. http://dx.doi.org/10.1016/j.tourman.2004.11.007

Sánchez-Fernández, R., \& Iniesta-Bonillo, M. Á. (2007). The concept of perceived value: A systematic review of the research. Marketing Theory, 7(4), 427-451. http://dx.doi.org/10.1177/1470593107083165

Sawhney, M., Wolcott, R. C., \& Arroniz, I. (2011). The 12 different ways for companies to innovate. Sloan Management Review, 47(3), 28-34.

Sharma, N., \& Patterson, P. G. (2000). Switching costs, alternative attractiveness and experience as moderators of relationship commitment in professional, consumer services. International Journal of Service Industry Management, 11(5), 470-490. http://dx.doi.org/10.1108/09564230010360182

Sinha, I., \& DeSarbo, W. S. (1998). An integrated approach toward the spatial modeling of perceived customer value. Journal of Marketing Research, 35(2), 236-249. http://dx.doi.org/10.2307/3151851

Statista (2015). Global number of mobile-only internet users from 2010 to 2015 (in millions). Retrieved from http://www.statista.com/statistics/271389/number-ofworldwide-mobile-only-internet-users/

Stock, R. M. (2011). How does product program innovativeness affect customer satisfaction? A comparison of goods and services. Journal of the Academy of Marketing Science, 39, 813-827. http://dx.doi.org/10.1007/s11747-010-0215-4

Stone, Mervyn. (1974). Cross-validatory choice and assessment of statistical predictions. Journal of the Royal Statistical Society, B36, 111-147.

Sweeney, J. C., \& Soutar, G. N. (2001). Consumer perceived value: The development of a multiple item scale. Journal of Retailing, 77(2), 203-220. http://dx.doi. org/10.1016/S0022-4359(01)00041-0

Teke, A., Cengiz, E., Çetin, M., Demir, C., Kirkbir, F., \& Fedai, T. (2012). Analysis of the multi-item dimensionality of patients' perceived value in hospital services. Journal of Medical Systems, 36(3), 1301-1307. http://dx.doi.org/10.1007/s10916010-9590-0

Too, L. H., Souchon, A. L., \& Thirkell, P. C. (2001). Relationship marketing and customer loyalty in a retail setting: A dyadic exploration. Journal of Marketing Management, 17(3-4), 287-319. 
Toufaily, E., Richard, L., \& Perrien, J. (2013). Customer loyalty to a commercial website: Descriptive meta-analysis of the empirical literature and proposal of an integrative model. Journal of Business Research, 66(9), 1436-1447. http://dx.doi. org/10.1016/j.jbusres.2012.05.011

Ulaga, W., \& Chacour, S. (2001). Measuring customer-perceived value in business markets: A prerequisite for marketing strategy development and implementation. Industrial Marketing Management, 30(6), 525-540. http://dx.doi.org/10.1016/ S0019-8501(99)00122-4

van Riel, \& Allard C. R. (2012). Strategic service innovation management in retailing. In J. Kandampully, Service management (pp. 83-95). New York: Springer.

Wagstaff, J., \& Lee, C. Y. (2013, July 23). For the mobile internet, tomorrow belongs to Asia. The Star. Retrieved from http://www.thestar.com.my/News/World/2013/07/23/ For-the-mobile-Internet-tomorrow-belongs-to-Asia/

Wang, C. L., \& Ahmed, P. K. (2004). The development and validation of the organisational innovativeness construct using confirmatory factor analysis. European Journal of Innovation Management, 7(4), 303-313. http://dx.doi. org/10.1108/14601060410565056

Wang, Y., Lo, H. P., Chi, R., \& Yang, Y. (2004). An integrated framework for customer value and customer-relationship-management performance: A customerbased perspective from China. Managing Service Quality, 14(2/3), 169-182. http://dx.doi.org/10.1108/09604520410528590

Williams, P., \& Soutar, G. N. (2009). Value, satisfaction and behavioral intentions in an adventure tourism context. Annals of Tourism Research, 36(3), 413-438. http://dx.doi.org/10.1016/j.annals.2009.02.002

Wu, L. Y., Chen, K. Y., Chen, P. Y., \& Cheng, S. L. (2014). Perceived value, transaction cost, and repurchase-intention in online shopping: A relational exchange perspective. Journal of Business Research, 67(1), 2768-2776. http://dx.doi.org/10.1016/j. jbusres.2012.09.007

Xie, K., Xiong, L., Chen, C. C., \& Hu, C. (2011). Understanding active loyalty in hotel reward programs through customers' switching costs and perceived program value. Paper presented at the International CHRIE Conference.

Yanamandram, V. K., \& White, L. (2006). Switching barriers in business-to-business services: A qualitative study. International Journal of Service Industry Management, 17(2), 158-192. http://dx.doi.org/10.1108/09564230610656980

Zeithaml, V. A. (1988). Consumer perceptions of price, quality, and value: A means-end model and synthesis of evidence. Journal of Marketing, 52(3), 2-22. http://dx.doi. org/10.2307/1251446

Zins, A. H. (2001). Relative attitudes and commitment in customer loyalty models: Some experiences in the commercial airline industry. International Journal of Service Industry Management, 12(3), 269-294. http://dx.doi.org/10.1108/ EUM0000000005521 
